\title{
Proapoptotic and Antimigratory Effects of Pseudevernia furfuracea and Platismatia glauca on Colon Cancer Cell Lines
}

\author{
Dragana S. Šeklić ${ }^{*}$, \\ Ana D. Obradović, \\ Milan S. Stanković', \\ Marko N. Živanović', \\ Tatjana Lj. Mitrović, \\ Slaviša M. \\ Stamenković ${ }^{2}$ and \\ Snežana D. Marković ${ }^{1}$
}

'Department for Biology and Ecology, Faculty of Science, Radoja Domanovića 12, RS-34000 Kragujevac, Serbia 2Department of Biology and Ecology, Faculty of Science and Mathematics, Višegradska 33, RS-18000 Niš, Serbia

Received: 14 February 2018 Accepted: 28 June 2018

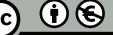

*Corresponding author:

Phone: +38134336223 (ext. 233);

Fax: +38134335040;

E-mail:ddjacic@yahoo.com

ORCID IDs: 0000-0002-2093-5335 (Šeklić), 0000-0002-6372-1062 (Obradović), 0000-0001-9861-7700 (Stanković), 0000-0002-8833-8035 (Živanović), 0000-0001-5341-9831 (Mitrović), 0000-0003-2284-4733 (Stamenković), 0000-0002-3892-8977 (Marković)

\section{SUMMARY}

The aim of this study is to investigate cytotoxic, proapoptotic, antimigratory and pro-antioxidant effects of methanol, acetone and ethyl acetate extracts of lichens Pseudevernia furfuracea and Platismatia glauca on colorectal cancer (HCT-116 and SW-480) cell lines. We compared the cytotoxic effects on colorectal cancer cells with the effects obtained from normal human fibroblast (MRC-5) cell line. Tetrazolium (MTT) test evaluated the cytotoxic effects, Transwell assay evaluated cell migration, acridine orange/ethidium bromide (AO/EB) fluorescent method followed the apoptosis, while prooxidant/antioxidant effects were determined spectrophotometrically through concentration of redox parameters. The tested extracts showed considerable cytotoxic effect on cancer cells with no observable cytotoxic effect on normal cells. Ethyl acetate and acetone extract of $P$. furfuracea induced the highest cytotoxicity $\left(I C_{50}=(21.2 \pm 1.3) \mu \mathrm{g} / \mathrm{mL}\right.$ on HCT-116, and $I C_{50}=(51.3 \pm 0.8) \mu \mathrm{g} / \mathrm{mL}$ on SW- 480 cells, respectively, after $72 \mathrm{~h}$ ), with noteworthy apoptotic and prooxidant effects, and antimigratory potential of methanol extract. P. glauca extracts induced cytotoxic effects on HCT-116 cells after $72 \mathrm{~h}\left(\mathrm{IC}_{50}<40 \mu \mathrm{g} / \mathrm{mL}\right)$, while only methanol and acetone extracts had cytotoxic effects on SW-480 cells after $24 \mathrm{~h}$, with proapoptotic/necrotic activity, as a consequence of induced oxidative stress. In conclusion, lichen extracts changed to a great extent cell viability and migratory potential of colorectal cancer cell lines. HCT-116 cells were more sensitive to treatments, P. furfuracea had better proapoptotic and antimigratory effects, and both investigated lichen species might be a source of substances with anticancer activity.

Key words: apoptosis, colorectal cancer, cytotoxic effects, lichen extracts, cell motility, redox status

\section{INTRODUCTION}

Colorectal cancer (CRC) is among major causes of mortality in the world, and the second cause of cancer-related death (1). Carcinogenesis is a multistage process with progressive changes at the cellular, genetic and epigenetic level. The main characteristics of cancer cells are proliferation, inactivated tumour suppressor genes, suppressed and inactivated genes and pathways responsible for cell death and capacity to migrate to other organs (2). Generally, treatment options for CRC patients are surgery, chemotherapy and radiation. Novel anticancer therapeutic strategies find basis in the activation of programmed cell death (apoptosis) and the suppression of cell migration (2). The activation of apoptosis is a key molecular mechanism responsible for anticancer activities of most of the currently studied potential anticancer agents (2). Oxidative stress and reactive oxygen species (ROS) as signal molecules have a major role in many physiological and pathological processes in cells (3). Overproduction of ROS induces the cytotoxic activity and apoptosis induction by various anticancer agents (e.g. cisplatin, camptothecin, inostamycin, doxorubicin and mitomycin C) (4), and some active compounds isolated from natural sources (5). Also, the reduction of cell migration, as a critical process in cancer development, depends on the production of ROS and reactive nitrogen species (RNS) in the treatments with anticancer drugs (6).

Natural sources (plants, mushrooms and lichens) contain different active substances with antitumour activity. Great number of drugs isolated from natural sources are approved 
for use in traditional medicine (7). Lichens have been widely used in the folk medicine as laxatives and antiemetic, which indicates their application in treatments of gastrointestinal disorders (8). Lichens synthesize a plenty of secondary metabolites with diverse biological activities (9). Also, many studies have shown that extracts of lichen species obtained from different areas in Serbia had antioxidant, antimicrobial and antiproliferative potential (10-12). Pseudevernia furfuracea (L.) Zopf. demonstrated a notable cytotoxic effect (in acetone extract) on the FemX (human melanoma) and LS174 (human coIon carcinoma) cell lines (11). In addition, Platismatia glauca (L.) W.L. Culb. \& C.F. Culb. had considerable cytotoxic effects (in $n$-hexane extracts) on L1210 (murine leukemia), 3LL (murine Lewis lung carcinoma) and U251 (human glioblastoma) (13). The literature data confirm that some active substances, such as acids isolated from lichens, can induce apoptosis in murine leukemia L1210 cell (13).

Recently, Mitrović et al. (14) have shown that extracts of $P$. glauca and $P$. furfuracea had antioxidant, antimicrobial and antibiofilm effects, and also gave the chemical profile of these extracts. The goal of this study is to evaluate cytotoxic, proapoptotic, antimigratory and pro-antioxidant impact of the methanol, acetone end ethyl acetate extracts of $P$. furfuracea and $P$. glauca lichen species from Serbia on two colorectal cancer cell lines (HCT-116 and SW-480). For estimation of antitumour effects, we also evaluated cytotoxicity of lichen extracts on normal human fibroblast MRC-5 cell line.

\section{MATERIALS AND METHODS}

\section{Lichen samples and extraction}

The lichen samples of Pseudevernia furfuracea (L.) Zopf. and Platismatia glauca (L.) W.L. Culb. \& C.F. Culb. were collected from two locations on Tara mountain, Kaludjerske bare, Solotuša, Serbia: $43^{\circ} 53^{\prime} 17.7^{\prime \prime} \mathrm{N}, 19^{\circ} 33^{\prime} 21.2^{\prime \prime} \mathrm{E}$ and $43^{\circ} 53^{\prime} 32.2^{\prime \prime} \mathrm{N}$, $19^{\circ} 33^{\prime} 25.0^{\prime \prime} \mathrm{E}$, as described by Mitrović et al. (14), who also described the procedure of extraction of powdered ( $A 11$ basic analytical mill, IKA, Staufen, Germany) lichen material with different solvents (methanol, acetone and ethyl acetate; Zorka Pharma, Šabac, Serbia) (14). During the extraction, the extracts were filtered through the Whatman no. 1 filter paper (Sigma Chemicals Co., Merck, St Louis, MO, USA) and then concentrated in a rotary vacuum evaporator (WU-28710-00; IKA). Lichen extracts were dissolved in $0.5 \%$ dimethyl sulfoxide (DMSO) (15) and conditional Dulbecco's modified Eagle medium (DMEM) with $10 \%$ fetal bovine serum (FBS), 100 IU/ $\mathrm{mL}$ penicillin and $100 \mu \mathrm{g} / \mathrm{mL}$ streptomycin (Gibco, Invitrogen, Thermo Fisher Scientific, New York, NY, USA) in final concentration of $1 \mathrm{mg} / \mathrm{mL}$.

\section{Cell culture}

The human colon cancer HCT-116, SW-480 and normal human fibroblast MRC-5 cell lines were obtained from the American Tissue Culture Collection, Manassas, VA, USA. The cells were maintained and seeded in a 96-well plate as described by Šeklić et al. (16). MRC-5 cell line was seeded only for tetrazolium (MTT) assay. Untreated cells served as negative control. The results for MTT, acridine orange/ethidium bromide (AO/EB) staining, nitroblue tetrazolium (NBT), Griess and glutathione (GSH) tests were obtained after 24 and $72 \mathrm{~h}$. For Transwell migration assay the results were measured 24 $\mathrm{h}$ after incubation.

\section{Cytotoxicity assay}

Cell viability was determined by MTT assay as described by Šeklić et al. (16). The concentrations of the three used lichen extracts (methanol, acetone and ethyl acetate) were 1, $10,50,100,250$ and $500 \mu \mathrm{g} / \mathrm{mL}$. The results were presented as percentage of viability (ratio between the absorbance of treated and control cells). IC $C_{50}$ values (the extract dose that inhibited cell growth by $50 \%$ ) served as the measure of cytotoxicity and were calculated by CalcuSyn v. 2.1 (17).

\section{Fluorescence microscopic analysis of cell death}

For the analysis of the stages of cell death in control and treated cells, we used AO/EB and double staining fluorescent microscopic assays according to the procedure described by Mitrović et al. (12). For this method, HCT-116 and SW-480 cells were treated with $100 \mu \mathrm{L}$ of each extract at two selected concentrations (10 and $100 \mu \mathrm{g} / \mathrm{mL}$ ). The cells were observed under the fluorescence microscope Eclipse Ti (Nikon Instruments Inc., Melville, NY, USA) at 400× magnification using Nikon NIS-Elements Advanced Research software v. 3.2 (18).

\section{Transwell migration assay}

Transwell migration assay (19) measured the effects of lichen extracts on the cell migration. Šeklić et al. (16) described a detailed protocol. The HCT-116 and SW-480 cells were treated with two selected concentrations (10 and $50 \mu \mathrm{g} / \mathrm{mL}$ ) of methanol lichen extracts, and the results were presented as index of migration/absorbance $(A)(19)$, and (index of migration $/ A) / N($ viable cells), respectively.

\section{Determination of redox status parameters}

Monitoring the concentrations of superoxide anion radical, nitrites and reduced glutathione (GSH) following detailed protocols described by Šeklić et al. (16) helped determine the prooxidant/antioxidant status. These parameters were determined in the four selected concentrations of each extract (1, 10,50 and $100 \mu \mathrm{g} / \mathrm{mL}$ ).

The colour reaction in MTT, Transwell, NBT, nitrites and GSH tests was measured spectrophotometrically on RT-2100C ELISA microplate reader (Hamburg, Germany). The results for NBT, nitrites and GSH tests were expressed in $\mu M$ per number of viable cells on the basis of data given in MTT test according to Živanović et al. (20). 


\section{Statistics}

All data are presented as the mean value \pm standard error (S.E.) of three independent experiments, in triplicate for each dose. Student's t-test and one-way ANOVA for multiple comparisons evaluated statistical significance using SPSS for Windows, v. 17 (21).

\section{RESULTS AND DISCUSSION}

\section{Cytotoxic activity}

Fig. 1 shows the effects of treatments with methanol, acetone and ethyl acetate extracts of Pseudevernia furfuracea and Platismatia glauca on colorectal cell viability, while Table 1 shows cytotoxic activities of the tested extracts, expressed via $\mathrm{IC}_{50}$ values. All treatments considerably decreased cell viability
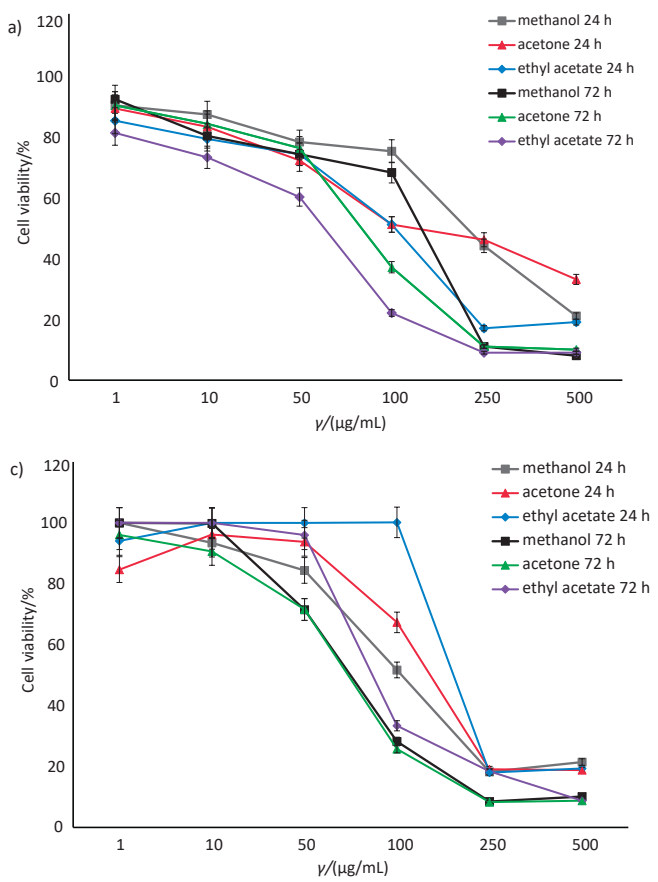

in dose- and time-dependent manner (except the P. glauca extracts in lower dose on SW-480 cells) of tested cancer cell lines (Fig. 1) and had moderate effect on normal MRC-5 cells (Table 1).

The most significant cytotoxic effect was observable of ethyl acetate extract of $P$. furfuracea on HCT-116 cells $\left(\mathrm{IC}_{50}=(21.2 \pm 1.3\right.$ $\left.I C_{50} \mu \mathrm{g} / \mathrm{mL}\right)$ ) after $72 \mathrm{~h}$. Acetone extract of $P$. furfurace a after $72 \mathrm{~h}$ had the highest cytotoxic effect on SW-480 cells. All extracts of $P$. glauca demonstrated significant cytotoxic effect $\left(\mathrm{IC}_{50}<40 \mu \mathrm{g} /\right.$ $\mathrm{mL}$ ) on HCT- 116 cell line after $72 \mathrm{~h}$, while methanol and acetone extracts of $P$. glauca had significant cytotoxic effects on SW-480 cells after $24 \mathrm{~h}$. The literature data defined criteria for cytotoxicity of the extracts as $\mathrm{IC}_{50}<30 \mu \mathrm{g} / \mathrm{mL}$ (22) and according to this criterion, ethyl acetate extract of $P$. furfuracea expressed significant cytotoxicity on HCT-116 cell line. As our results showed, all tested samples demonstrated cytotoxic effect on both cell lines, while HCT-116 cells were more sensitive to treatments.
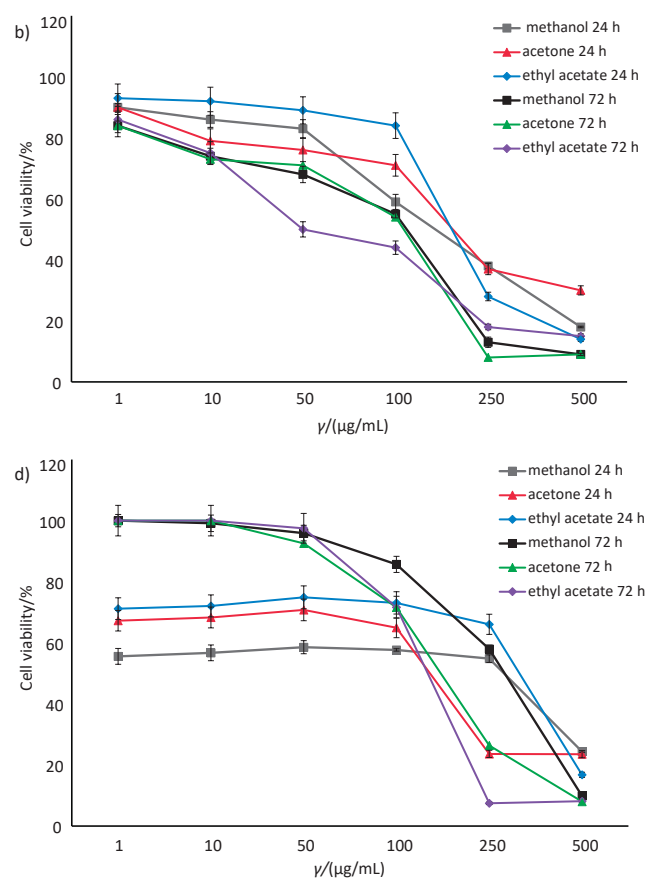

Fig. 1. The effects of methanol, acetone and ethyl acetate extracts of Pseudevernia furfuracea and Platismatia glauca on HCT-116 and SW-480 colorectal cancer cell viability: a) HCT-116 cells, P. furfuracea, b) HCT-116 cells, P. glauca, c) SW-480 cells, P. furfuracea, and d) SW-480 cells, P. glauca. All values are mean \pm S.E., $N=3$

Table 1. Growth inhibitory effects, expressed as $\mathrm{IC}_{50}$ values $(\mu \mathrm{g} / \mathrm{mL})$, of methanol, acetone and ethyl acetate extracts of Pseudevernia furfuracea and Platismatia glauca extracts on HCT-116, SW-480 and MRC-5 cell lines after 24 and $72 \mathrm{~h}$ of exposure

\begin{tabular}{|c|c|c|c|c|c|}
\hline \multirow{2}{*}{\multicolumn{2}{|c|}{ Extract }} & \multirow{3}{*}{$\begin{array}{l}t / \mathrm{h} \\
24\end{array}$} & \multicolumn{3}{|c|}{$\mathrm{IC}_{50} /(\mu \mathrm{g} / \mathrm{mL})$} \\
\hline & & & HCT-116 & SW-480 & MRC-5 \\
\hline \multirow{6}{*}{ P. furfuracea } & \multirow{2}{*}{ methanol } & & $215.7 \pm 12.9$ & $105.0 \pm 2.6$ & $226.8 \pm 0.6$ \\
\hline & & 72 & $57.8 \pm 9.1$ & $77.9 \pm 1.1$ & $371.8 \pm 0.5$ \\
\hline & \multirow{2}{*}{ acetone } & 24 & $176.4 \pm 9.1$ & $86.6 \pm 1.0$ & $225.7 \pm 0.8$ \\
\hline & & 72 & $41.9 \pm 6.6$ & $51.3 \pm 0.8$ & $201.4 \pm 1.1$ \\
\hline & \multirow{2}{*}{ ethyl acetate } & 24 & $62.4 \pm 5.5$ & $294.46 \pm 0.05$ & $394.3 \pm 0.9$ \\
\hline & & 72 & $21.2 \pm 1.3$ & $142.0 \pm 0.8$ & $256.0 \pm 0.1$ \\
\hline \multirow{6}{*}{ P. glauca } & \multirow{2}{*}{ methanol } & 24 & $115.3 \pm 12.9$ & $56.4 \pm 1.5$ & $414.3 \pm 0.1$ \\
\hline & & 72 & $38.2 \pm 4.5$ & $197.1 \pm 0.5$ & $389.1 \pm 0.6$ \\
\hline & \multirow{2}{*}{ acetone } & 24 & $205.0 \pm 12.0$ & $60.2 \pm 0.3$ & $246.1 \pm 1.0$ \\
\hline & & 72 & $34.3 \pm 2.5$ & $206.9 \pm 0.1$ & $380.93 \pm 0.06$ \\
\hline & \multirow{2}{*}{ ethyl acetate } & 24 & $184.9 \pm 12.9$ & $421.2 \pm 2.5$ & $442.2 \pm 0.8$ \\
\hline & & 72 & $37.7 \pm 4.1$ & $173.8 \pm 1.6$ & $216.6 \pm 0.4$ \\
\hline
\end{tabular}

Results are expressed as the mean value \pm S.E. of three independent experiments 
Concerning the results obtained with $P$.glauca, the present study revealed significant cytotoxicity of all tested extracts on HCT-116 cells after $72 \mathrm{~h}$, while the highest effect of methanol and acetone extracts was on SW-480 cells after $24 \mathrm{~h}$. Based on the obtained results, we can conclude that the $P$. glauca extract induces a significantly acute cytotoxic effect. The literature data show that extracts of lichen may have significant cytotoxic effects on colon cancer cells after $24 \mathrm{~h}$ (23). The investigated treatment with $P$. glauca in low concentrations activated proliferation in survivor cells and the effects of proliferation were measured after $72 \mathrm{~h}$ (higher $\mathrm{IC}_{50}$ values after $72 \mathrm{~h}$ ).

In our earlier study, chemical profiling of $P$. glauca extract revealed dimethyl caperate, atraric acid, chloratranol and atranol as major components (14). We must be aware of the presence of other minor components (5,7-dihydroxy-6-methylphtalide, isoadiantone, olivetol, methyl and ethyl haematommate) and their hidden contribution to the detected cytotoxic activity.

However, normal human fibroblast MRC-5 cell line is modestly sensitive to treatments $\left(\mathrm{IC}_{50}>200 \mu \mathrm{g} / \mathrm{mL}\right.$ ) (Table 1), thus indicating cell-specific activities of tested lichen extracts. According to the data presented in our study, P. furfuracea and
P. glauca extracts might be considered a possible source of anticancer agents.

\section{Proapoptotic effects}

Our results show that the tested extracts induced cell death mainly by apoptosis. The treated cells showed morphological changes typical for apoptosis (reduction of cell size, blabbing effects with condensation and fragmentation of nuclear material, and formation of apoptotic bodies) (Fig. 2). Table 2 shows the percentages of viable, early apoptotic, late apoptotic and necrotic cells in HCT- 116 and SW- 480 cell lines, respectively. The number of viable cells detected with MTT assay (Fig. 1) correlates with the number of viable and early apoptotic cells observed by microscopic AO/EB double staining, as a more sensitive assay. The literature data (23) confirm that cells in the early apoptosis still have the capacity to metabolize the tetrazolium salt (the main component of the MTT test), and according to the MTT test, they are detected as living. It is also known that cellular adhesion is not impaired in the early apoptosis, so the cells at this stage are still attached to the plate, i.e. they are detected as alive (23). The changes of molecules responsible for

a)
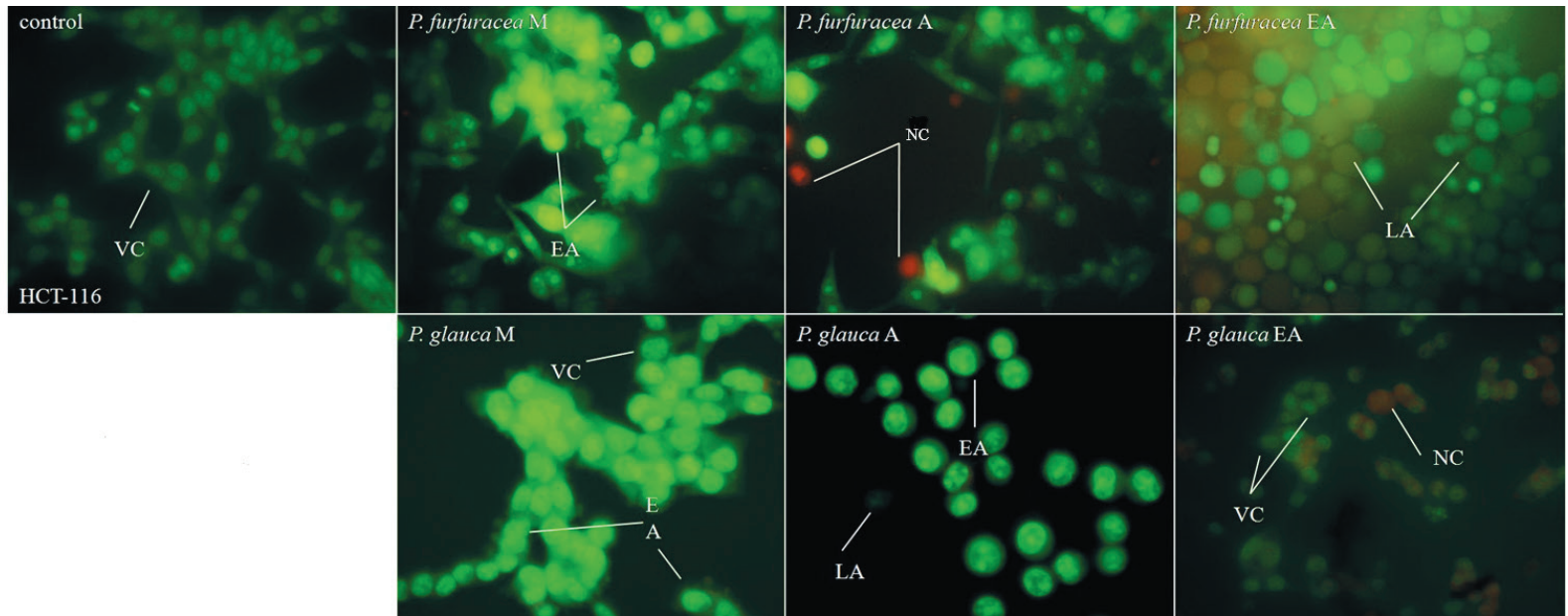

b)
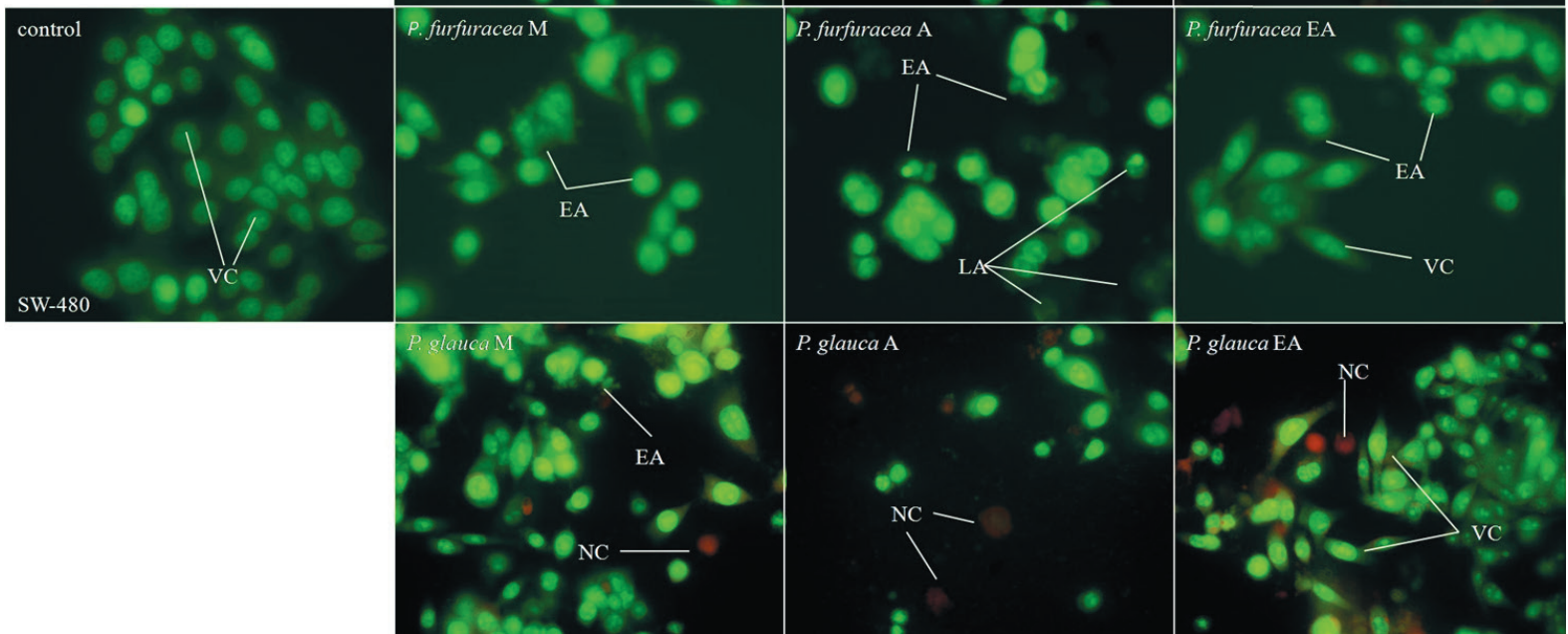

Fig. 2. Acridine orange/ethidium bromide (AO/EB) staining of: a) HCT-116, and b) SW-480 colorectal cancer cells for determination of the stages of cell death induced by methanol, acetone and ethyl acetate extracts of Pseudevernia furfuracea and Platismatia glauca. Untreated cells were observed as a negative control. $\mathrm{VC}=$ viable cells, $E A=$ early apoptosis, $L A=$ late apoptosis, $N C=$ necrotic cells 
Table 2. Effects of methanol, acetone and ethyl acetate extracts of Pseudevernia furfuracea and Platismatia glauca on the stage of cell death in HCT-116 and SW-480 cells

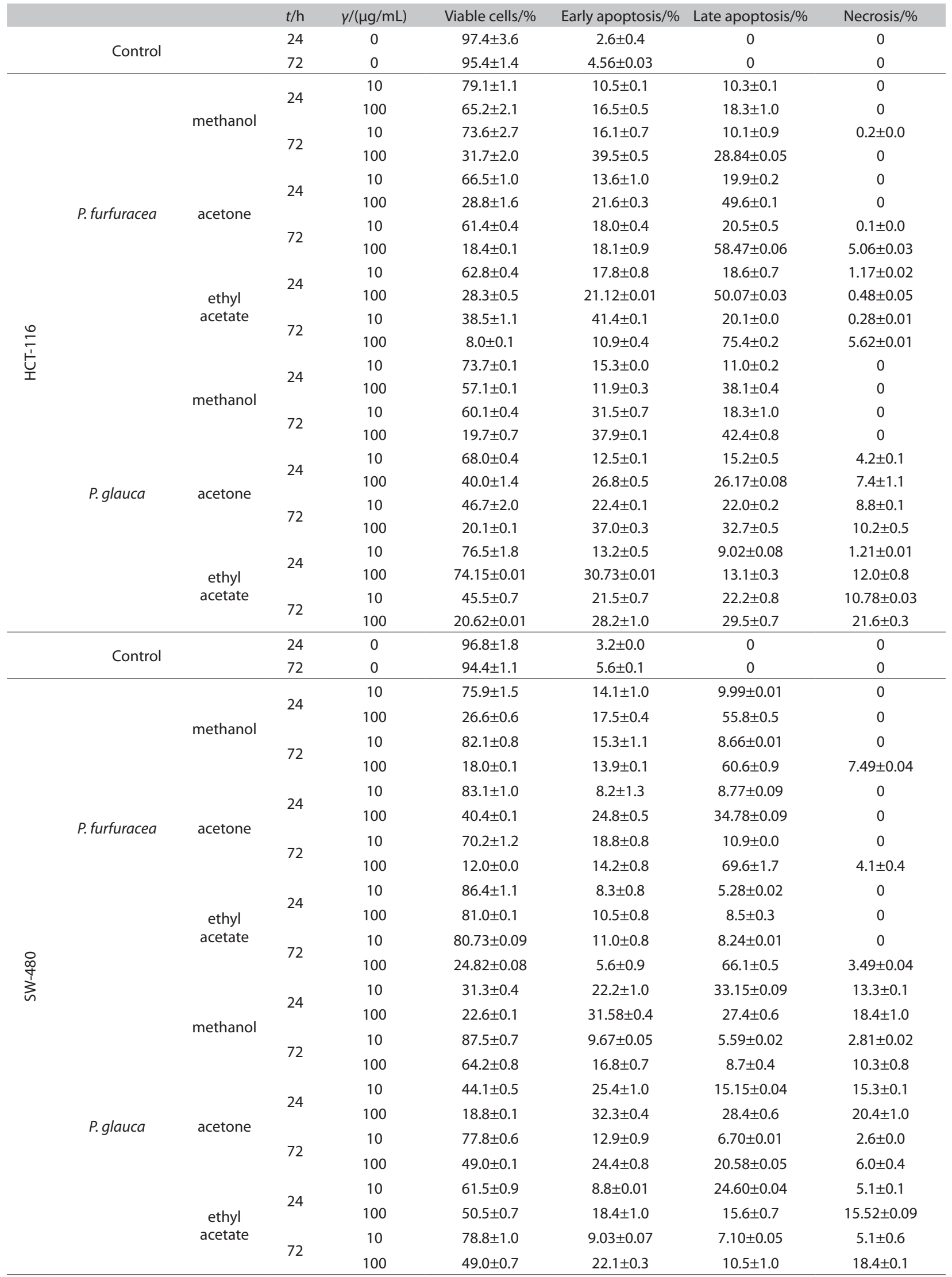

Results are expressed as the mean value \pm S.E. of three independent experiments 
cell adhesion and mitochondrial dysfunction, and for the metabolism of tetrazolium, are characteristic of cells in late stages of apoptosis (formation of apoptotic bodies) and necrosis, so that these cells are detected as dead by the MTT test (23). Besides, cytotoxic effects of the extracts tested in this study, evaluated by MTT test, were the consequence of late apoptotic and necrotic cells, recognized as dead cells, because only nonviable cells accumulated ethidium bromide and emitted red fluorescence in AO/EB double staining.

According to the data presented in Table 2, apoptotic effects depend on the concentration of treatments and time of exposure. Stronger effects were observed after longer exposure time (72 h), except for P. glauca extract tested on SW-480 cells, which showed better results after $24 \mathrm{~h}$ (Table 2). The ethyl acetate extract of $P$. furfuracea, with the strongest cytotoxic effects at HCT- 116 cells after $72 \mathrm{~h}$, showed a significant apoptotic effect at both tested doses $(10 \mu \mathrm{g} / \mathrm{mL}$ caused $20.12 \%$ of late apoptotic cells, while $100 \mu \mathrm{g} / \mathrm{mL}$ induced $75.39 \%$ of late apoptotic cells and $5.62 \%$ of necrotic cells; Table 2 ). A significant percentage of viable cells detected by MTT were in the early apoptosis stage (41.37 and $10.94 \%$ in the presence of 10 and $100 \mu \mathrm{g} / \mathrm{mL}$ ethyl acetate extract of $P$. furfuracea, respectively), indicating that this lichen extract possessed very strong proapoptotic potential against HCT- 116 cells. The extracts of $P$. glauca induced significant, dose- and time-dependent proapoptotic effects on HCT-116 cells. However, the acetone and ethyl acetate extracts of $P$. glauca induced modest necrotic effects on the same cells. Regarding the induced apoptosis on HCT-116 cells, the extracts of $P$. furfuracea could be ranged as follows: ethyl acetate $>$ acetone $>$ methanol, and of $P$. glauca: methanol $>$ ethyl acetate $>$ acetone (Table 2 ).

The results presented in Table 2 show that methanol and acetone extracts of $P$. furfuracea had the highest proapoptotic effects on SW-480 cells after $72 \mathrm{~h}$, which was in accordance with the results of the cytotoxicity $\left(\mathrm{IC}_{50}\right.$ values in Table 1$)$. The methanol and acetone extracts of $P$. glauca induced higher apoptotic effects on SW-480 cells after $24 \mathrm{~h}$ of exposure (Table 2 ). Regarding the induced apoptosis in SW-480 cells, P. furfuracea extracts could be ranged as follows: acetone $>$ methanol $>$ ethyl acetate, and of P. glauca: methanol>acetone > ethyl acetate (Table 2). All $P$. furfuracea extracts had modest necrotic effects on SW-480 cells (3.49-7.49\%), but only in higher dose $(100 \mu \mathrm{g} /$ $\mathrm{mL}$ ) after $72 \mathrm{~h}$. However, P. glauca extracts demonstrated the strongest necrotic effects on the same cells, in both tested doses and treatment periods (Table 2). The methanol and acetone extracts of $P$. glauca had the highest necrotic potential after 24 $h$, and together with induced apoptosis, these data clearly coincided with the cytotoxic activity $\left(\mathrm{IC}_{50}\right.$ values in Table 1$)$ and may be a consequence of oxidative stress (24). Generally, the cytotoxic effects of $P$. furfuracea extracts were the consequence of induced apoptosis in HCT-116 and SW-480 cells, while P. glauca extracts induced apoptosis and necrosis in both cell lines, especially $72 \mathrm{~h}$ after treatments. According to the presented data, lichen extracts with the highest cytotoxic effects had the strongest proapoptotic effects on the tested cancer cell lines.
A few studies $(12,13,23)$ demonstrate the induction of apoptosis in cancer cells by lichen metabolites. Apoptosis, as a strongly regulated process of programed cell death, can be induced via two main pathways, the extrinsic (death receptor pathway) and the intrinsic (mitochondrial pathway) (25). The literature data show that the treatment with lichen extracts induces the genomic DNA fragmentation with significant elevation of caspase 3 activities in cancer cells (26). All tested extracts, especially $P$. furfuracea extracts, induce nuclear condensation and cell damage in apoptotic process, indicating that the tested extracts have a potential to eliminate tumour cells by apoptosis. According to the obtained results, we can conclude that HCT-116 cells are more sensitive to proapoptotic effects of lichen extracts.

\section{Migratory potential}

Cell migration is a key problem during the development and progression of cancer. Thus, we evaluated antimigratory potential of methanol extracts of $P$. furfuracea and $P$. glauca on HCT-116 and SW-480 cells. The methanol extract was selected because it had the weakest cytotoxicity on the tested cell lines after $24 \mathrm{~h}$ (except the extracts of $P$. glauca on SW-480 cells). The 10 and $50 \mu \mathrm{g} / \mathrm{mL}$ methanol extracts of tested lichens considerably decreased migration of HCT-116 and SW-480 cells (Fig. 3). After the evaluation of absorbance related to the number of viable cells, all methanol extracts of $P$. furfuracea and $P$. glauca showed noteworthy antimigratory effects on HCT- 116 cells. Further, the tested extracts showed antimigratory effects on the SW-480 cells, except the P. glauca extract at the lower concentration $(10 \mu \mathrm{g} / \mathrm{mL})$, thus demonstrating promigratory effect. As the literature data confirmed, a significant change in the prooxidant/antioxidant balance could have an impact on the stimulation of cellular mobility $(27,28)$. On the other hand, $P$. glauca extract induced multiple increase in GSH in SW-480 cells, indicating an antioxidant effect. A high level of GSH in cancerous cells allowed them to survive oxidative stress by favouring the survival of cells with high invasive and metastatic potential $(28,29)$.

P. furfuracea extract $(50 \mu \mathrm{g} / \mathrm{mL})$ revealed the best antimigratory effects in both cell lines (Fig. 3). In the literature, there are a few studies that focus on the effects of whole polyphenol extracts on migration and metastatic potential of cancer in vitro $(30,31)$. To the best of our knowledge, there are no data about the effects of the tested lichen species extracts on cell migratory potential, and our study is the first to show the antimigratory potential of $P$. furfuracea and $P$. glauca on colorectal cancer HCT-116 and SW-480 cell lines. Our results suggest stronger antimigratory capacity of $P$. furfuracea than $P$. glauca probably according to their chemical profile. The comparison of the obtained results revealed that methanol extract of $P$. furfuracea was richer in phenols than the same extract of $P$. glauca (14), thus suggesting that the phenols participated in antimigratory effects on the tested cancer cells. The literature data confirmed that polyphenolic compounds could suppress cell migration and reverse metastatic cells $(31,32)$. 
The results presented in this work indicate that HCT-116 cells are more sensitive to antimigratory effects of the investigated lichen species than SW-480 cells, which agrees with our earlier findings on migratory potential of these cell lines (33).

\section{Redox status}

As a very potent and significant member of reactive oxygen species (ROS), the superoxide anion radical indicates the

a)

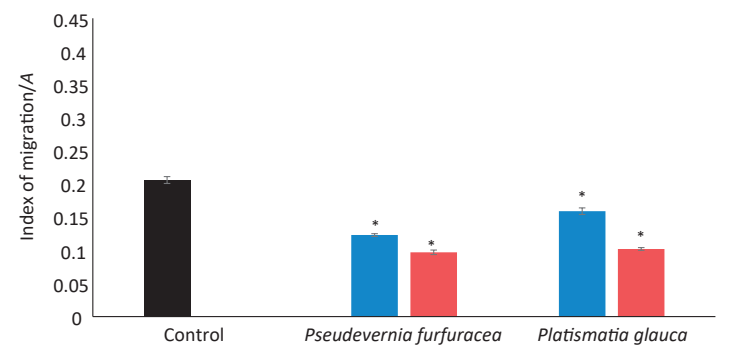

c)

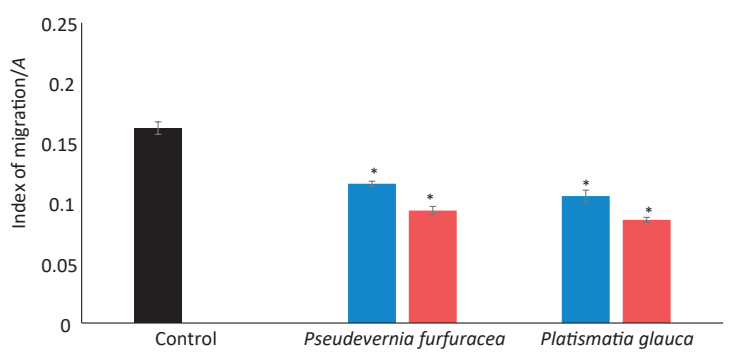

occurrence of oxidative stress in supraphysiologically high concentration. Fig. 4. shows the effects of methanol, acetone and ethyl acetate extracts of $P$. furfuracea and $P$. glauca on $\mathrm{O}_{2}^{--}$level in HCT-116 and SW-480 cells, expressed per number of cells. Generally, all treatments were prooxidative, with increased $\mathrm{O}_{2}{ }^{--}$level, mainly in dose- and time-dependent way. Higher concentrations of extracts ( 50 and $100 \mu \mathrm{g} / \mathrm{mL}$ ) considerably increased $\mathrm{O}_{2}{ }^{-}$- levels in both cell lines, and the highest prooxidative effect was observed in P. furfuracea (Fig. 4). b)
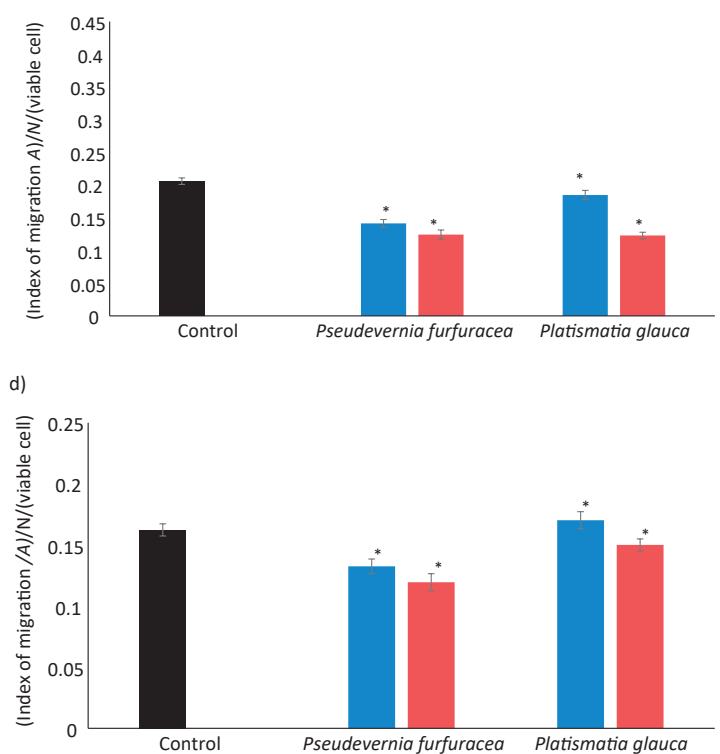

Fig. 3. Effects of Pseudevernia furfuracea and Platismatia glauca methanol extracts on migratory potential of: a and b) HCT-116, and c and d) SW-480 colorectal cancer cells. The results measured after $24 \mathrm{~h}$ of exposure represent index of migration/absorbance $(A)$ and (index of migration $/ A) / N($ viable cells). All values are mean \pm S.E., $N=3$; * $p<0.05$ as compared with control
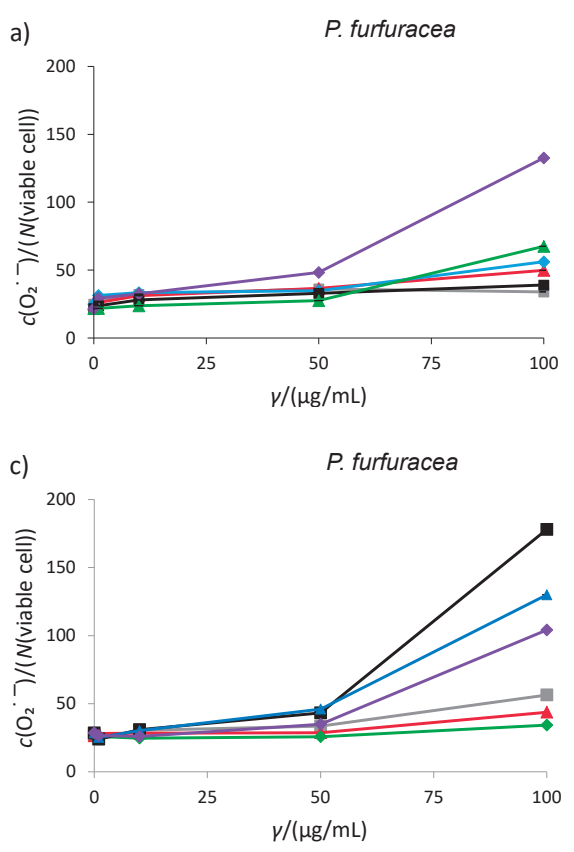
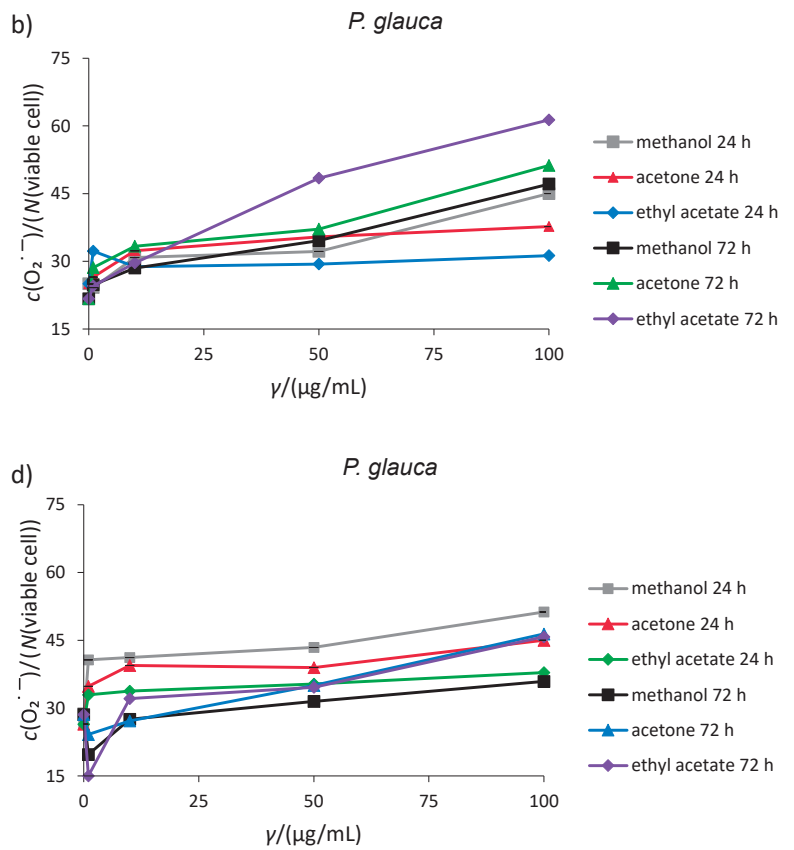

Fig. 4. The concentration of $\mathrm{O}_{2}^{--}$in: $\mathrm{a}$ and b) HCT-116, and c and d) SW-480 colorectal cancer cells treated with methanol, acetone and ethyl acetate extracts of Pseudevernia furfuracea and Platismatia glauca. The parameters are expressed as $c\left(\mathrm{O}_{2}{ }^{\circ}\right) / \mu \mathrm{M}$ per $N($ viable cells). All values are mean $\pm \mathrm{S}$.E., $N=3$ 
High concentrations of nitrites (as an indicator of nitric oxide) could be a parameter of nitrosative stress in cells. We investigated the nitrite level and showed the obtained data in Fig. 5. Generally, all tested lichen extracts showed doseand time-dependent increase of nitrite level in HCT-116 cells. In lower doses, this increase of nitrites was not as prominent as in higher doses. P. furfuracea extracts induced greater nitrite increase than $P$. glauca extracts. On the other hand, we also observed nitrite increase in SW-480 cells, but in a slightly different way. Lower concentrations of $P$. furfuracea induced very slow nitrite elevation with the increase of applied extract doses, and only the highest dose induced extreme nitrite rise, especially after $72 \mathrm{~h}$ at treatment. On the other hand, after 24 h of treatment, P. glauca induced greater increase at lowest concentrations, thus reaching the plateau of effect with almost no change in the increase of extract doses. After $72 \mathrm{~h}$, the increase of nitrites was dose-dependent. P. glauca induced greater nitrite levels after $24 \mathrm{~h}$ than after $72 \mathrm{~h}$. We conclude that $P$. furfuracea had greater impact on the tested cell lines than the lichen species.

The reduced glutathione (GSH) content is considered a very important parameter of cell antioxidative capacity. In our experiments, all treatments predominantly induced decrease of GSH at low concentrations and increase in higher concentrations, depending on a lichen species, type of extract, concentration and treatment period (Fig. 6). P. furfuracea induced greater increase of GSH level in the investigated cells, especially in SW-480 after $72 \mathrm{~h}$ of treatment. P. glauca induced greater increase in HCT-116 cells, while the investigated extracts induced notable GSH increase in SW-480 cells, in low doses and after $24 \mathrm{~h}$ of treatment.

a)

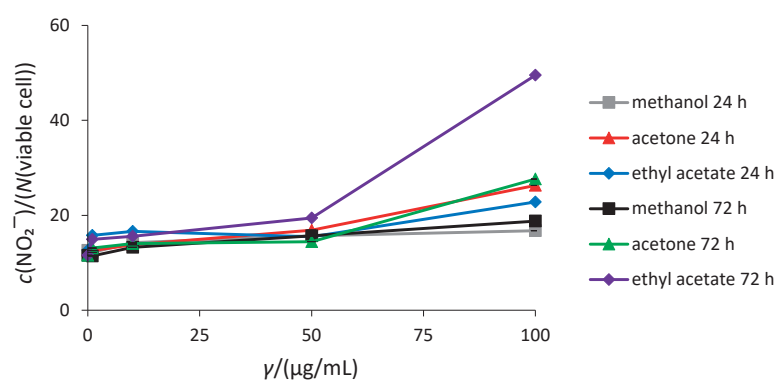

c)

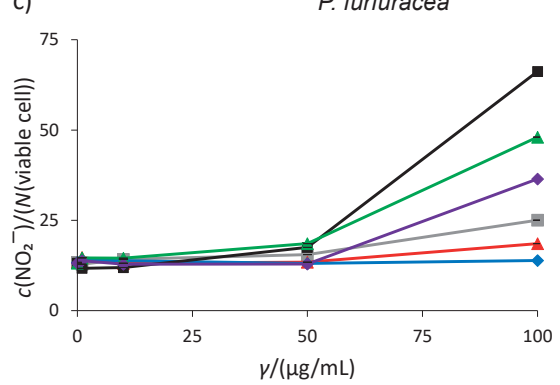

Considering the given parameters of redox status in relation to the number of viable cells, we concluded that the treated cancer cells were in oxidative stress. All the measured parameters $\left(\mathrm{O}_{2}{ }^{-}, \mathrm{NO}_{2}{ }^{-}\right.$and $\left.\mathrm{GSH}\right)$ considerably increased at higher concentrations, mainly $72 \mathrm{~h}$ after treatments. P. furfuracea induced higher oxidative stress in both tested cell lines than P. glauca extracts.

It is known that lichen extracts and purified components could change oxidative characteristics of cancer cells and that the ROS overproduction has important role in the cytotoxicity, the initiation and execution of apoptosis $(4,26)$. According to our results, the investigated cells were under great oxidative/nitrosative stress, which induced enhanced cytotoxicity through apoptosis. These effects were the most prominent with $P$. furfuracea extracts. De novo generated nitrites spontaneously combine with $\mathrm{O}_{2}{ }^{--}$and generate peroxynitrites, which are considered very reactive and toxic reactive nitrogen species (RNS) with notable cytotoxic and proapoptotic effects (33). Our results showed that prooxidative capacity (increased $\mathrm{O}_{2}^{-}$) of $P$. furfuracea and $P$. glauca methanol extracts directly correlated with their antimigratory effects on the treated colon cancer cell lines. The literature data (6) confirmed that ROS, in the first instance $\mathrm{O}_{2}^{--}$and $\mathrm{H}_{2} \mathrm{O}_{2}$, could reduce migratory potential of cancer cells.

Glutathione as a parameter of antioxidative protection of cells is the most abundant redox pool of cells, and depletion of reduced glutathione content could be the consequence of antioxidant response of the tested cells to the increased oxidative stress (34). Our results show that GSH content increased in HCT-116 and more evidently in SW-480 cells. These findings suggest that the tested colorectal cell lines had different response to the same treatment. As a consequence of
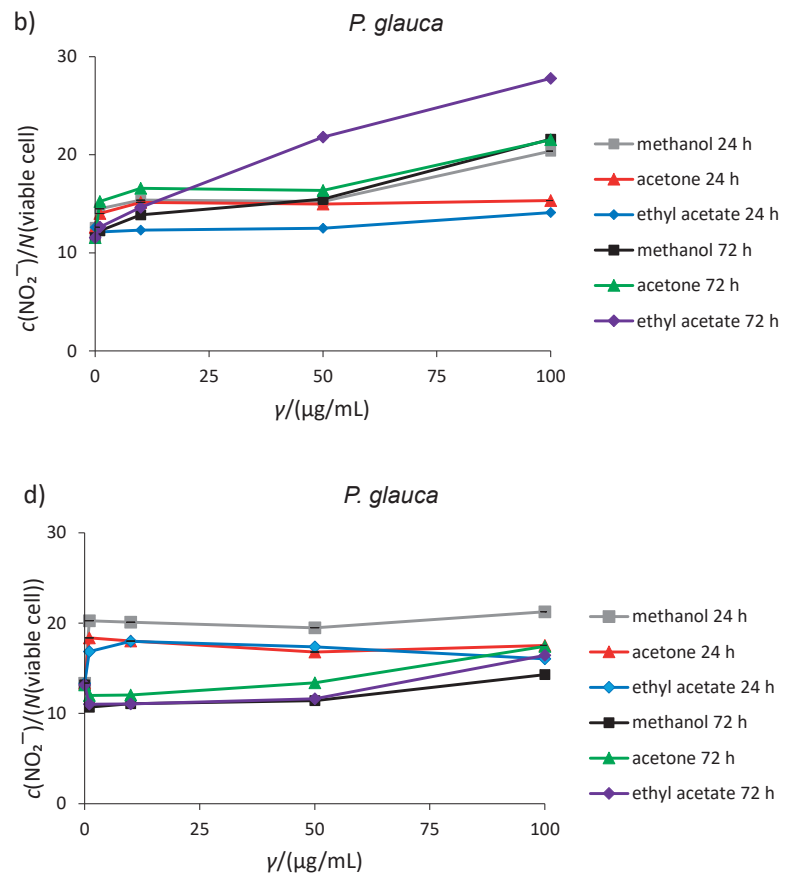

Fig. 5. The concentration of $\mathrm{NO}_{2}{ }^{-}$in: $\mathrm{a}$ and b) $\mathrm{HCT}-116$, and $\mathrm{c}$ and d) SW-480 colorectal cancer cells treated with methanol, acetone and ethyl acetate extracts of Pseudevernia furfuracea and Platismatia glauca. The parameters are expressed as $c\left(\mathrm{NO}_{2}{ }^{-}\right) / \mu \mathrm{M}$ per $N($ viable cells). All values are mean \pm S.E., $N=3$ 
a)

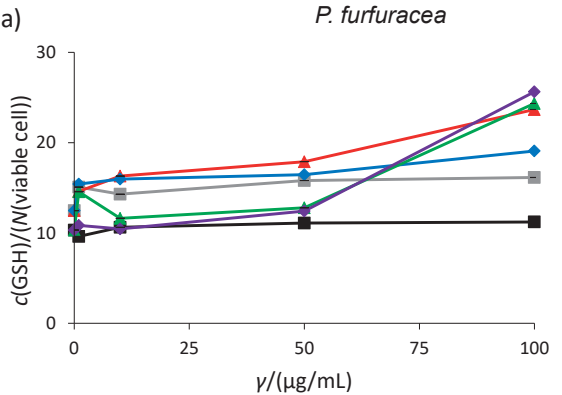

c)

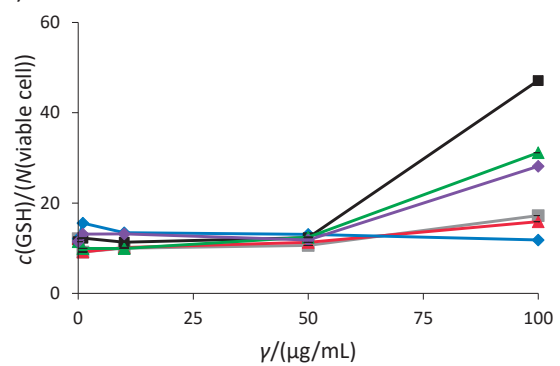

b)
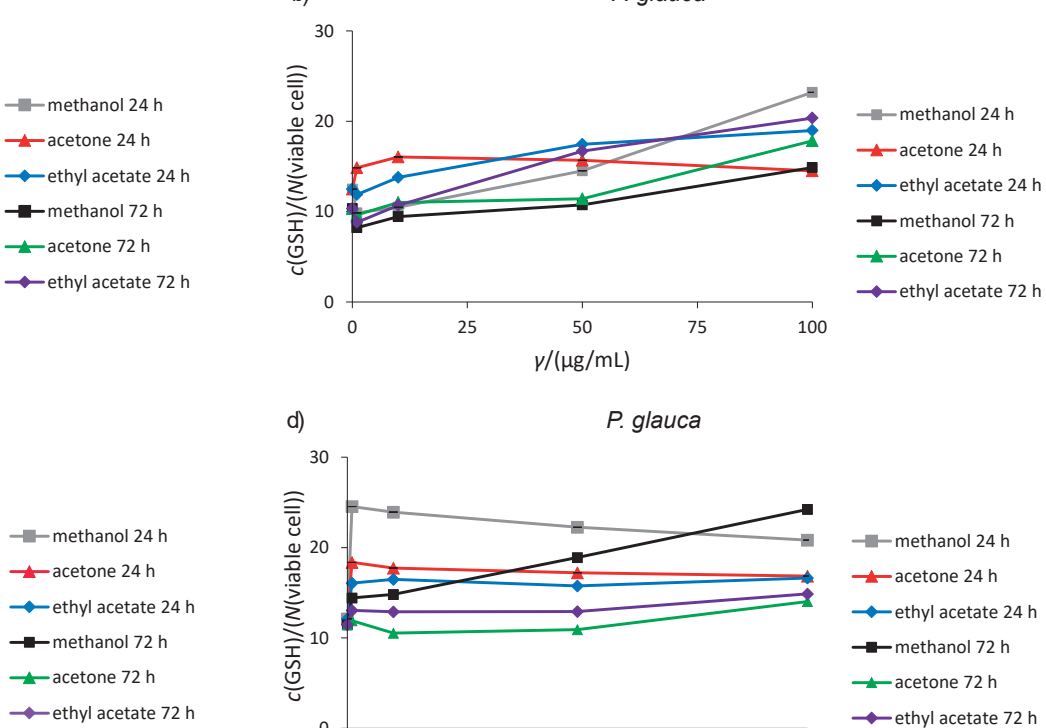

d)

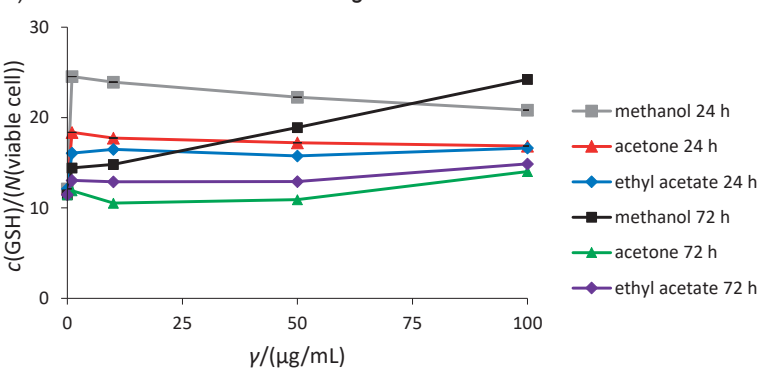

Fig. 6. The concentration of glutathione (GSH) in: a and b) HCT-116, and c and d) SW-480 colorectal cells treated with methanol, acetone and ethyl acetate extracts of Pseudevernia furfuracea and Platismatia glauca. The parameters are expressed as $c(\mathrm{GSH}) / \mu \mathrm{M}$ per $N($ viable cells). All values are mean \pm S.E., $N=3$

the genetic defect in the hMLH1 gene and deficiency in DNA mismatch repair (MMR) of HCT-116 cells, this phenotype becomes more prone to oxidative stress than SW-480 cells (35).

\section{CONCLUSIONS}

Lichen species Pseudevernia furfuracea and Platismatia glauca demonstrated relevant cytotoxic, proapoptotic, prooxidative and antimigratory effects on colorectal cancer cells (HCT-116 and SW-480), without observable cytotoxic effects on normal MRC-5 cells lines. The ethyl acetate extract of $P$. furfuracea showed the strongest antitumour activity and this species might be considered for deeper investigation into potential anticancer action. Further studies will elucidate specific factors of these activities within $P$. furfuracea and explain molecular mechanisms of their action.

\section{ACKNOWLEDGEMENTS}

This work was supported by the Ministry of Education, Science and Technological Development of the Republic of Serbia (project nos. III-41010 and III-41018).

\section{REFERENCES}

1. Hagan S, Orr MCM, Doyle B. Targeted therapies in colorectal cancer-an integrative view by PPPM. EPMA J. 2013;4(1):3-7. https://doi.org/10.1186/1878-5085-4-3

2. Anand P, Kunnumakkara AB, Sundaram C, Harikumar KB, Tharakan ST, Lai OS, et al. Cancer is a preventable disease that requires major lifestyle changes. Pharm Res. 2008;25(9):2097-116.

https://doi.org/10.1007/s11095-008-9661-9
3. Dröge W. Free radicals in the physiological control of cell function. Physiol Rev. 2002;82(1):47-95.

https://doi.org/10.1152/physrev.00018.2001

4. Fang, J, Nakamura $\mathrm{H}$, lyer AK. Tumor-targeted induction of oxystress for cancer therapy. J Drug Target. 2007;15(7-8):47586.

\section{https://doi.org/10.1080/10611860701498286}

5. Russo SE, Zhang L, Tan S. Covariation between understorey light environments and soil resources in Bornean mixed dipterocarp rain forest. J Tropical Ecol. 2012;28(1):33-44. https://doi.org/10.1017/S0266467411000538

6. Luanpitpong S, Talbott SJ, Rojanasakul Y, Nimmannit U, Pongrakhananon V, Wang L, Chanvorachote P. Regulation of lung cancer cell migration and invasion by reactive oxygen species and caveolin-1. J Biol Chem. 2010;285(50):3832-40. https://doi.org/10.1074/jbc.M110.124958

7. Cragg GM, Newman DJ. Plants as a source of anti-cancer agents. J Ethnopharmacol. 2005;100(1-2):72-9. https://doi.org/10.1016/j.jep.2005.05.011

8. Shukla V, Joshi GP, Rawat MSM. Lichens as a potential natural source of bioactive compounds: A review. Phytochem Rev. 2010;9(2):303-14. https://doi.org/10.1007/s11101-010-9189-6

9. Molnár K, Farkas E. Current results on biological activities of lichen secondary metabolites: A review. Z Naturforsch C. 2010;65(3-4):157-73.

https://doi.org/10.1515/znc-2010-3-401

10. Kosanić M, Ranković B. Lichen as possible sources of antioxidants. Pak J Pharm Sci. 2011;24:165-70. 
11. Kosanić M, Manojlović N, Janković S, Stanojković T, Ranković B. Evernia prunastri and Pseudoevernia furfuraceae lichens and their major metabolites as antioxidant, antimicrobial and anticancer agents. Food Chem Toxicol. 2013;53:112-8. https://doi.org/10.1016/j.fct.2012.11.034

12. Mitrović T, Stamenković S, Cvetković V, Tošić S, Stanković $\mathrm{M}$, Radojević I, et al. Antioxidant, antimicrobial and antiproliferative activities of five lichen species. Int J Mol Sci. 2011;12(8):5428-48.

https://doi.org/10.3390/ijms12085428

13. Bézivin C, Tomasi S, Rouaud I, Delcros JG, Boustie J. Cytotoxic activity of compounds from the lichen: Cladonia convoluta. Planta Med. 2004;70(9):874-7.

https://doi.org/10.1055/s-2004-827240

14. Mitrović T, Stamenković S, Cvetković V, Radulović N, Mladenović M, Stanković M, et al. Platismatia glauca and Pseudevernia furfuracea lichens as sources of antioxidant, antimicrobial and antibiofilm agents. EXCLI J. 2014;13:938-53.

15. Hostanska K, Jürgenliemk G, Abel G, Nahrstedt A, Saller R. Willow bark extract (BNO1455) and its fractions suppress growth and induce apoptosis in human colon and lung cancer cells. Cancer Detect Prev. 2007;31(2):129-39.

https://doi.org/10.1016/j.cdp.2007.03.001

16. Šeklić DS, Stanković MS, Milutinović MG, Topuzović MD, Štajn AŠ, Marković SD. Cytotoxic, antimigratory and pro/antioxidative activities of extracts from medicinal mushrooms on colon cancer cell lines. Arch Biol Sci. 2016;68(1):93-105.

https://doi.org/10.2298/ABS150427131S

17. CalcuSyn, v. 2.1, BioSoft, Great Shelford, Cambridge, UK; 2009.

18. NIS-Elements Advanced Research, v. 3.2, Nikon Instruments Europe B.V., Amsterdam, The Netherlands; 2008.

19. Chen HC. Boyden chamber assay. Methods Mol Biol. 2005;294:15-22.

20. Živanović MN, Košarić JV, Šmit B, Šeklić DS, Pavlović RZ, Marković SD. Novel seleno-hydantoin palladium(II) complex-Antimigratory, cytotoxic and prooxidative potential on human colon HCT-116 and breast MDA-MB-231 cancer cells. Gen Physiol Biophys. 2017;36(2):187-96.

https://doi.org/10.4149/gpb_2016036

21. SPSS Statistics, v. 17, IBM Corporation, Armonk, NY, USA; 2008.

22. Itharat A, Houghton PJ, Eno-Amooquaye, E, Burke PJ, Sampson $\mathrm{JH}$, Raman A. In vitro cytotoxic activity of Thai medicinal plants used traditionally to treat cancer. J Ethnopharmacol. 2004;90(1):33-8.

https://doi.org/10.1016/j.jep.2003.09.014

23. Bačkorová $M$, Jendželovský R, Kello $M$, Bačkor M, Mikeš J, Fedoročko P. Lichen secondary metabolites are responsible for induction of apoptosis in HT-29 and A2780 human cancer cell lines. Toxicol in Vitro. 2012;26(3):462-8.

https://doi.org/10.1016/j.tiv.2012.01.017

24. Henslee EA, Torcal Serrano RM, Labeed FH, Jabr RI, Fry $\mathrm{CH}$, Hughes MP, Hoettges KF. Accurate quantification of apoptosis progression and toxicity using a dielectrophoretic approach. Analyst. 2016;141(23):6408-15.

https://doi.org/10.1039/C6AN01596D

25. Galluzzi L, Maiuri MC, Vitale I, Zischka H, Castedo M, Zitvogel L, Kroemer G. Cell death modalities: classification and pathophysiological implications. Cell Death Differ. 2007;14(7): 1237-43.

https://doi.org/10.1038/sj.cdd.4402148

26. Igney FH, Krammer PH. Death and anti-death: Tumor resistance to apoptosis. Nat Rev Cancer. 2002;2(4):277-88.

https://doi.org/10.1038/nrc776

27. Russo SE, Brown P,Tan S, Davies SJ. Interspecific demographic trade-offs and soil-related habitat associations of tree species along resource gradients. J Ecol. 2008;96(1):192-203.

https://doi.org/10.1111/j.1365-2745.2007.01330.x

28. Fiaschi T, Chiarugi P. Oxidative stress, tumor microenvironment, and metabolic reprogramming: A diabolic liaison. International J Cell Biol. 2012;Article ID 762825.

https://doi.org/10.1155/2012/762825

29. Carretero J, Obrador E, Esteve JM, Ortega A, Pellicer JA, Sempere FV, Estrela JIM. Tumoricidal activity of endothelial cells inhibition of endothelial nitric oxide production abrogates tumor cytotoxicity induced by hepatic sinusoidal endothelium in response to B16 melanoma adhesion in vitro. J Biol Chem. 2001;276(28):25775-82.

https://doi.org/10.1074/jbc.M101148200

30. Saha A, Kuzuhara T, Echigo N, Suganuma M, Fujiki H. New role of (-)-epicatechin in enhancing the induction of growth inhibition and apoptosis in human lung cancer cells by curcumin. Cancer Prev Res. 2010;3(8):953-62.

https://doi.org/10.1158/1940-6207.CAPR-09-0247

31. Niedzwiecki A, Roomi MW, Kalinovsky T, Rath M. Anticancer efficacy of polyphenols and their combinations. Nutrients. 2016;8(9):552.

https://doi.org/10.3390/nu8090552

32. Lee SH, Jaganath IB, Wang SM, Sekaran SD. Antimetastatic effects of Phyllanthus on human lung (A549) and breast (MCF-7) cancer cell lines. PLoS ONE. 2011;6(6):e20994.

https://doi.org/10.1371/journal.pone.0020994

33. Ferdinandy P. Peroxynitrite: Just an oxidative/nitrosative stressor or a physiological regulator as well? Br J Pharmacol. 2006;148(1):1-3. https://doi.org/10.1038/sj.bjp.0706693

34. Kranner I, Grill D. Desiccation of lichens: Changes in the glutathione status. In: Brunold C, Cram WJ, De Kok LJ, Rennenberg $\mathrm{H}$, Stulen I, editors. Sulphur metabolism in higher plants. Fundamental molecular, ecophysiological and agricultural aspects. Leiden, The Netherlands: Backhuys Publishers; 1997. pp. 253-5.

35. Liu L, Taverna P, Whitacre CM, Chatterjee S, Gerson SL. Pharmacologic disruption of base excision repair sensitizes mismatch repair-deficient and -proficient colon cancer cells to methylating agents. Clin Cancer Res. 1999;5(10):2908-17. 